\title{
Ada apa dengan mutu pelayanan fakultas di perguruan tinggi ? : Implementasi manajemen sumber daya manusia
}

\author{
Muh. Azhar Burhanuddin a,1,*, H. Azhar Arsyad a,2, H. Arifuddin Siraj a,3, Hj. St. Syamsudduha a,3 \\ ${ }^{a}$ UIN Alauddin Makassar, Jl. Sultan Alauddin No.63, Romangpolong, Kec. Somba Opu, Kabupaten Gowa, Sulawesi Selatan 92113, Indonesia \\ 1 azharbarlet@yahoo.com* \\ * Korespondensi Penulis
}

ARTICLE INFO

Article history

Received June 26, 2020

Revised June 26, 2020

Accepted June 27, 2020

Available Online June 30, 2020

Keywords

Quality of service

Human resource management

Mutu pelayanan

Fakultas

Perguruan tinggi

Manajemen SDM

\section{ABSTRACT}

This study discusses the Implementation of Human Resource Management in Improving the Quality of Service of the Tarbiyah and Teaching Faculty of UIN Alauddin Makassar, which aims to determine the process of implementing human resource management in improving the quality of services carried out by the Tarbiyah and Teaching Faculty of UIN Alauddin Makassar; describe the supporting factors and inhibiting factors in the implementation of human resource management in the Faculty of Tarbiyah and Teacher Training at UIN Alauddin Makassar; and found the results of the implementation of human resource management in improving service quality at the Tarbiyah and Teacher Training Faculty of UIN Alauddin Makassar. This research is a qualitative research using theological, managerial and sociological approaches. The data source of this study consisted of the Dean, Deputy Dean, Kabag. TU, Kasubag, several staff, and students. Data collection techniques used were in-depth interviews, observation and documentation study. Data Analysis Techniques use the technique of reducing, presenting, and verifying data or drawing conclusions. Data validity testing uses data triangulation techniques. The results showed that: 1) The process of implementing human resource management in improving the quality of service at the Tarbiyah and Teaching Faculty of UIN Alauddin Makassar, showed that it was in accordance with standards or regulations. 2) While the supporting factors, namely the Stakeholders fully support the policies and programs of the faculties with a collective system of cologists, training soft skills and hard skills, giving the widest possible space for self-development, the availability of arts stage facilities and sports week and good collaboration with the management of the institution student affairs. The inhibiting factors are budget constraints, regulations, communication affordability, senior employees who need special jobs, and if the central server is down. 3) The quality of service management at the Tarbiyah and Teaching Faculty of UIN Alauddin Makassar turns out to show better development, but it still requires optimal coaching efforts so that the quality of service management exceeds customer expectations. 
Kajian ini membahas Implementasi Manajemen Sumber Daya Manusia dalam Perbaikan Mutu Pelayanan Fakultas Tarbiyah dan Keguruan UIN Alauddin Makassar, yang bertujuan untuk mengetahui proses implementasi manajemen sumber daya manusia dalam perbaikan mutu pelayanan yang dilaksanakan oleh Fakultas Tarbiyah dan Keguruan UIN Alauddin Makassar; mendeskripsikan faktor pendukung dan faktor penghambat implementasi manajemen sumber daya manusia di Fakultas Tarbiyah dan Keguruan UIN Alauddin Makassar; dan menemukan hasil implementasi manajemen sumber daya manusia dalam perbaikan mutu pelayanan di Fakultas Tarbiyah dan Keguruan UIN Alauddin Makassar. Penelitian ini adalah penelitian kualitatif yang menggunakan pendekatan teologis, manajerial dan sosiologis. Sumber data penelitian ini terdiri dari Dekan, Wakil Dekan, Kabag. TU, Kasubag, beberapa orang Staf, dan Mahasiswa. Teknik pengumpulan data yang digunakan adalah metode wawancara mendalam, observasi dan studi dokumentasi. Teknik Analisa Data menggunakan teknik reduksi, penyajian, dan verifikasi data atau penarikan kesimpulan. Pengujian keabsahan data menggunakan teknik trianggulasi data. Hasil penelitian menunjukkan bahwa: 1) Proses implementasi manajemen sumber daya manusia dalam perbaikan mutu pelayanan Fakultas Tarbiyah dan Keguruan UIN Alauddin Makassar, menunjukkan telah sesuai dengan standar atau aturan. 2) Sementara faktor pendukungnya yakni Stakeholder mendukung sepenuhnya mengenai kebijakan dan program-program fakultas dengan sistem kolektif kologial, pelatihan soft skill dan hard skill, memberi ruang seluas luasnya untuk pengembangan diri, ketersediaan fasilitas panggung seni dan pekan olah raga dan kerjasama baik dengan pengurus lembaga kemahasiswaan. Faktor penghambatnya yakni keterbatasan anggaran, regulasi, keterjangkauan komunikasi, pegawai yang sudah senior membutuhkan pekerjaan yang spesial, dan jika server pusat mengalami gangguan. 3) Adapun mutu manajemen layanan Fakultas Tarbiyah dan Keguruan UIN Alauddin Makassar ternyata menunjukkan perkembangan yang lebih baik, namun tetap masih diperlukan upaya pembinaan secara optimal agar mutu manajemen layanan melebihi harapan pelanggan.

This is an open access article under the CC-BY-SA license.

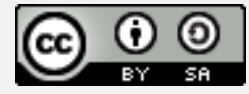

\section{Pendahuluan}

Pada era global semua satuan pendidikan di manapun akan dihadapkan pada tantangan global yaitu masa depan yang demikian ketat. Tantangan ini muncul akibat kehidupan yang makin transparan di antara bangsa-bangsa yang ada di dunia. ${ }^{1}$ Pembangunan di bidang pendidikan diarahkan kepada pengembangan sumber daya manusia yang bermutu tinggi guna memenuhi kebutuhan dan menghadapi tantangan dimasa depan. Melalui pendidikan, sumber daya manusia yang bersifat potensial diimplementasikan secara optimal dan seluruh aspek kepribadian dikembangkan secara terpadu.

Peraturan Menteri Agama Republik Indonesia No. 20 Tahun 2014, Statuta Universitas Islam Negeri Alauddin Makassar tentang Ketenagaan/ Sumber daya manusia. SDM/ Pegawai universitas terdiri dari dosen dan tenaga kependidikan. Dosen adalah pendidik profesional dan ilmuan dengan tugas utama mentransformasikan, mengembangkan dan menyebarluaskan ilmu pengetahuan dan teknologi melalui pendidikan, penelitian dan pengabdian kepada masyarakat. Adapun tenaga

${ }^{1}$ Saiful Sagala, Manajemen Strategik dalam Peningkatan Mutu Pendidikan, (Bandung: Alfabeta, 2004), h. 100. 
kependidikan adalah anggota masyarakat yang mengabdikan diri dan diangkat dengan tugas utama menunjang penyelenggaraan pendidikan tinggi di universitas. ${ }^{2}$

Menyadari pentingnya standarisasi SDM, pemerintah telah mengatur dalam Undang-undang No.12 Tahun 2012 tentang Pendidikan Tinggi Permenristekdikti 62 Tahun 2016 Tentang Sistem Penjaminan Mutu Pendidikan Tinggi, bahwa Penjabaran standar dikti ke standar turunan (SDM) Yakni rekrutasi, masa percobaan, perjanjian kerja, penilaian prestasi kerja, mutasi/ promosi/ demosi, waktu kerja, kerja lembur/ cuti, penghasilan/penghargaan, jamsos/kesejahteraan, pengembangan/pembinaan, $\mathrm{K} 3$, disiplin, perjalanan dinas \& pengakhiran kerja. ${ }^{3}$

Menyadari pentingnya standarisasi mutu pendidikan, pemerintah telah mengaturnya dalam Permenristekdikti No. 44 Tahun 2015, dan Tentang Standar Nasional Pendidikan Tinggi. Standar nasional pendidikan tinggi adalah satuan standar yang meliputi standar nasional pendidikan, ditambah dengan standar nasional penelitian, dan standar nasional pengabdian kepada masyarakat. standar nasional penelitian terdiri atas: standar komptensi kelulusan, standar isi, standar proses, standar penilaian, standar dosen dan tenaga kependidikan, standar sarana dan prasarana, standar pengelolaan, standar pembiayaan. ${ }^{4}$

Mewujudkan mutu pendidikan dan memberikanpelayanan yang memuaskan pelanggan bukanlah pekerjaan yang mudah danmembutuhkan tahapan dan proses yang berkelanjutan. Berdasarkan hal ini pemerintah telah mengatur dalam Undang-undang No.12 Tahun 2012 tentang Pendidikan Tinggi Permenristekdikti 62 Tahun 2016 Tentang Sistem Penjaminan Mutu Pendidikan Tinggi. Mutu pendidikan tinggi selain diukur dari pemenuhan setiap standar pendidikan tinggi, tetapi harus pula diukur dalam pemenuhan interaksi antar standar pendidikan tinggi untuk mewujudkan budaya mutu, yakni standar proses, standar dosen, standar isi, etc. ${ }^{5}$

Untuk memberikan jaminan terahadap mutu, perguruan tinggi harus melalukan pengelolaan lembaga yang berorientasi pada mutu. Mutu pendidikan perlu dikelola dengan tertib dan kontinyu agarmembawa hasil yang memuaskan. Maka diperlukan manajemen SDM untuk meningkatkan mutu pelayananpendidikan, hal tersebut mesti diperhatikan disebabkanpersaingan yang semakin kuat dan deras, dan ketergantungan yang menjerat. ${ }^{6}$

Untuk menambah wawasan terhadap masalah mutu, perlu diketengahkan konsep mutu dalam perspektif Islam, bahwa konsep ini sesungguhnya bukanlah sesuatu yang baru dalam pandangan

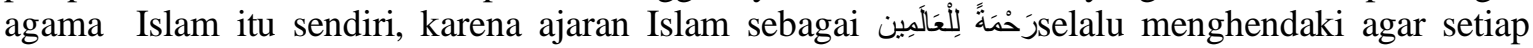
urusan/pekerjaan harus sesuai dengan tuntutan Islam, sehingga pekerjaan itu dapat bermanfaat bagi diri yang mengerjakannya maupun bagi orang lain. Pekerjaan yang produktif dan berkualitas merupakan salah satu perbuatan yang dianjurkan dalam Islam. Pandangan Islam tentang mutu, sungguh banyak ayat dalam al Qur'an. Islam juga selalu menekankan kepada umatnya untuk selalu berusaha mengubah nasib agar menjadi lebih baik sesuai dengan firmannya QS al-Ra'd/13:11.

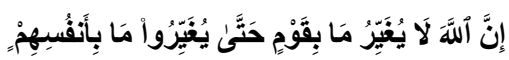

${ }^{2}$ Tim Redaksi Kemenag, Peraturan Menteri Agama RI No.20 Thn 2014 tentang Statuta UIN Alauddin Makassar, (Jakarta, 2014), h. 27.

${ }^{3}$ Johannes Gunawan, Kebijakan Nasional Sistem Penjaminan Mutu Internal, (Jakarta: Kemenrisetdikti, 2017), h. 6.

${ }^{4}$ Tim Redaksi Sinar Grafika, Permenristekdikti No. 44 Tahun 2015, tentangStandar Nasional Pendidikan Tinggi (Jakarta: Sinar Grafika, 2013), h. 2.

${ }^{5}$ Johannes Gunawan, Kebijakan Nasional Sistem Penjaminan Mutu Internal, h. 7.

${ }^{6}$ Nur Aedi, Dasar-Dasar Manajemen Pendidikan, (Yogyakarta: Gosyen, 2015), h.162. 


\section{Sesungguhnya Allah tidak merubah keadaan sesuatu kaum sehingga mereka merubah keadaan yang ada pada diri mereka sendiri. ${ }^{7}$}

Ayat tersebut menjelaskan bahwa Allah memerintahkan hambanya agar selalu berusaha memperbaiki hidupnya melalui usaha yang produktif.Produktifitas yang harus dicapai adalah kehidupan yang mengedepankan keseimbangan antara kepentingan ukhrawi dengan kepentingan duniawiyah.Menurut Ibnu Abi Zamanain,Konsep ini sudah berada pada tataran perbaikan mutu yang tidak dibatasi oleh ruang dan waktu untuk berusaha mencapai hasil terbaik secara berkesinambungan dengan menyeimbangkan unsur manusia dan proses produksi yang lebih ditekankan pada pencapaian mutu terbaik pada usaha atau proses tersebut. ${ }^{8}$

Allah menciptakan manusia sebagai mahluk yang sempurna, yang diberikan akal dan pikiran untuk menjalani hidup. Allah menciptakan manusia dengan melengkapi berbagai macam potensi (rohaniah dan aqliyah) bukanlah hal yang sia-sia, karena manusia diangkat menjadi khalifah dimuka bumi yang sekaligus membuktikan bahwa kualitas manusia lebih tinggi dan lebih terhormat bila dibandingkan dengan makhluk lainnya, akan tetapi ada sebuah persyaratan yang mesti dipenuhi agar manusia dikatakan manusia yang unggul atau berkualitas. Seperti yang dikatakan Allah dalam QS al-Zariyat/ 51: 56.

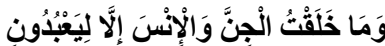

\section{Dan aku tidak menciptakan jin dan manusia melainkan supaya mereka mengabdi kepada-Ku. ${ }^{9}$}

Ayat ini memberi petunjuk bahwa manusia diwajibkan untuk beribadah kepada Allah Swt dengan kata lain diwajibkan mentaati perintahnya dan menjauhi larangan-larangannya, agar kehidupan manusia lebih berkualitas (Islami).

Perguruan tinggi Islam harus dapat menunjukkan eksistensinya sebagai perguruan tinggi yang mampu bersaing di era global yang akan banyak diminati oleh pengguna lembaga pendidikan karena mampu merespon tuntutan dan kebutuhan masyarakat secara luas. Untuk itu, lembaga pendidikan Islam harus secepatnya berbenah diri menjadi lembaga pendidikan unggul dan efektif serta mampu menunjukkan karakter Islaminya dalam merespons perkembangan pendidikan dan tuntutan pengguna pendidikan khususnya pendidikan Islam.

\section{Metode}

\subsubsection{Jenis Penelitian}

Penelitian tentang manajemen SDM dalam perbaikan mutu pelayanan ini menggunakan jenis penelitian kualitatif. Penelitian kualitatif pada hakikatnya mengamati orang dalam lingkungan hidupnya, berinteraksi dengan mereka, berusaha memahami bahasa dan tafsiran mereka tentang dunia sekitarnya. ${ }^{10}$ Penelitian kualitatif bertujuan untuk memperoleh data yang lebih lengkap, lebih mendalam, kredibel, dan bermakna, sehingga tujuan penelitian dapat dicapai.

\footnotetext{
${ }^{7}$ Kementerian Agama RI, Al-Qur'an Terjemahnya (Jakarta: PT. Tahazed, 2015) h. 273.

${ }^{8}$ Marwan bin Musa, Tafsir Al Qur'anil Azhiim (Isma'il bin Katsir)Maktabah Syamilahversi 3.45.
} h.237.

${ }^{9}$ Kementerian Agama RI, Al-Qur'an Terjemahnya, h. 471.

${ }^{10}$ Sugiyono, Memahami Penelitian Kualitatif (Cet. IV; Bandung: CV. Alfabeta, 2008), h.205. 
Mengkaji tentang manajemen SDM dalam perbaikan mutu pelayanan, peneliti bermaksud memahami realitas empirik dari fenomena-fenomena yang muncul untuk dipahami dan dimaknai berdasarkan interpretasi peneliti. Tentu saja, dalam memaknai dan menginterpretasikan informasi dan data, penulis menggunakan referensi untuk dijadikan acuan atau sandaran dan penguat data yang ditemukan di lapangan. Data yang dikumpulkan kemudian dideskripsikan berdasarkan ungkapan, bahasa, cara berpikir, dan pandangan subjek penelitian. Dalam hal ini, peneliti mengumpulkan datadata yang terkait dengan proses, faktor pendukung dan penghambat, hasil implementasi manajemen sumber daya Manusia dalam perbaikan mutu pelayanan.

\subsubsection{Waktu dan Tempat Penelitian}

Penelitian ini dilaksanakan pada Fakultas Tarbiyah dan Keguruan, Universitas Islam Negeri (UIN) Alauddin Makassar yang berlokasikan di Jl. H.M. Yasin LimpoNo.36 Samata-Gowa. Lokasinya sangat strategis disebabkan karena berbatasan dengan 3 kabupaten/ kota, yakni Makassar, Gowa dengan Maros.

\subsubsection{Teknik Pengumpulan Data}

Adapun pendekatan yang penulis gunakan dalam penelitian ini adalah pendekatan teologis, pendekatan manajerial dan pendekatan sosiologis, dan Ketiga pendekatan ini digunakan dengan pertimbangan sebagai berikut:

Pendekatan teologis, digunakan karena hubungan dengan staf/ pegawai beserta pimpinan sebagai konsepsi hidup manusia, melaksanakan tugas dengan penuh tanggung jawab, mempekerjakan seseorang sesuai keahliannya dan merupakan disiplin ilmu yang membicarakan hubungan antara manusia dengan penciptaNya. ${ }^{11}$

Pendekatan manajerial, digunakan untuk mengetahui hubungan, baik secara struktural dan koordinatif maupun secara administratif yang terkait dengan kinerja dan perilaku semua unsur pendidikan yang ada pada Fakultas Tarbiyah dan Keguruan sebagai sistem-sistem sosial yang berhubungan dengan dua orang atau lebih bersama sama dalam upaya mereka mencapai tujuan tujuan bersama dalam proses pengembangan mutu pelayanan pendidikan untuk memenuhi kebutuhan dan kepuasan pelanggan (mahasiswa).

Pendekatan sosiologis, yaitu peneliti dalam melakukan penelitian kualitatif, mempelajari secara inten situasi sosial yang terjadi pada obyek penelitian. Dalam membangun hubungan sosial peneliti harus menjaga sikap dan tindakan serta memelihara kehangatan dan keakraban. Peneliti hendaknya mudah bergaul, gampang menyesuaikan diri dengan segala macam situasi, menampakkan simpati secara jujur dan tidak dibuat-buat, menghargai perasaan dan pendapat subyeknya dan tetap tenang menghadapi situasi.

Sumber data primer adalah sumber data utama yang diperoleh peneliti secara langsung di lapangan yakni pengambilan data secara langsung dengan pihak-pihak yang terkait dengan masalah yang akan diteliti. ${ }^{12}$ Dalam memperoleh data ini peneliti berhadapan langsung dengan informan untuk mendapatkan data yang akurat, agar peneliti dalam melakukan pengolahan data tidak mengalami kesulitan. Sumber data primer dalam penelitian ini adalah Dekan, Wakil Dekan, Kepala KTU, bebarapa orang Staf, dan Mahasiswa Fakultas Tarbiyah dan Keguruan, UIN Alauddin Makassar. Data ini berupa hasil interview (wawancara).

Sumber data sekunder adalah sumber data pendukung atau penunjang yang bersumber dari informan tambahan ataupun dari literatur. Pengambilan data dalam bentuk dokumen yang telah ada serta hasil penelitian yang ditemukan peneliti secara tidak langsung. Data ini berupa dokumendokumen yang berkaitan dengan penelitian ini. Data ini berfungsi untuk menghindari data yang tidak valid yang didapatkan dari hasil penelitian dan menguatkan hasil temuan di lapangan.

${ }^{11}$ Nata, Abuddin. Metodologi Studi Islam (Cet.XI; Jakarta: PT. Raja Grafindo Persada, 2004), h.51.

${ }^{12}$ Moh. Kasiram, Metode penelitian Kualitatif-Kuantitatif,(Malang: UIN Malang Press, 2008), h. 231. 
Wawancara adalah suatu bentuk komunikasi verbal, semacam percakapan yang bertujuan memperoleh data yang mendalam dalam komunikasi tersebut yang dilakukan secara berhadapan. ${ }^{13}$ Observasi adalah pencatatan dan pengamatan langsung secara sistematis terhadap objek dan tempat yang diteliti. ${ }^{14}$ Teknik ini digunakan dalam rangka mengamati proses kegiatan secara menyeluruh, melakukan deskripsi terhadap semua yang dilihat, didengar dan dirasakan, serta mengamati secara langsung proses pembelajaran di ruang perkuliahan segala yang berkaitan dengan ini. Dokumentasi adalah proses pengumpulan, pemilihan, dan pengolahan naskah-naskah asli atau informasi-informasi tertulis yang dipergunakan sebagai alat pembuktian atau bahan untuk mendukung suatu keterangan atau argumen. ${ }^{15}$

\subsubsection{Instrumen}

Instrumen dalam penelitian kualitatif atau alat penelitian adalah peneliti sendiri. Peneliti sebagai instrumen utama yang berfungsi menetapkan fokus penelitian, memilih informasi sebagai sumber data, melakukan pengumpulan data, menilai kualitas data, analisis data, menafsirkan dan membuat kesimpulan atas temuannya. ${ }^{16}$

Pedoman wawancara adalah alat bantu berupa daftar-daftar pertanyaan yang dipakai dalam mengumpulkan data \& recorder. Panduan observasi adalah alat bantu yang dipakai sebagai pedoman pengumpulan data pada proses penelitian, dan Kamera. Format catatan, notebook/ buku tempat mencatat data yang diambil dari dokumen yang tertulis.

\subsubsection{Teknik Analisis Data}

Pada dasarnya analisis data adalah sebuah proses yang mengatur urutan data dan mengorganisasikannya kedalam suatu pola, kategori dan satuan uraian dasar sehingga dapat ditemukan tema dan rumusan kerja seperti yang didasarkan oleh data. Pekerjaan analisis data dalam hal mengatur, menguraikan, mengelompokkan, memberi kode, dan mengkategorikan data yang terkumpul, baik dari catatan lapangan, gambar, foto, atau dokumen berupa laporan. Untuk melaksanakan analisis data kualitatif ini, maka ditekankan beberapa tahapan dan langkah-langkah sebagai berikut:

Reduksi data, Miles dan Huberman mengatakan bahwa reduksi data diartikan sebagai proses pemilihan, pemusatan perhatian pada penyederhanaan, pengabstrakkan dan transformasi data yang kasar yang muncul dari catatan tertulis di lapangan. Mereduksi data bisa berarti merangkum, memilih hal-hal pokok, memfokuskan pada hal-hal yang penting, dicari tema dan polanya. ${ }^{17}$ Dengan demikian data yang telah direduksi akan memberikan gambaran yang lebih jelas, dan mencarinya bila diperlukan. ${ }^{18}$ Adapun tahapan-tahapan dalam reduksi data meliputi: membuat ringkasan, mengkode, menelusuri tema dan menyusun laporan secara lengkap dan terinci.

Penyajian data, Miles dan Huberman mengatakan bahwa yang dimaksud penyajian data adalah menyajikan sekumpulan informasi yang tersusun dan kemungkinan adanya penarikan kesimpulan dan pengambilan tindakan. ${ }^{19}$

Verifikasi data, Miles dan Hubermanmengungkapkan bahwa verifikasi data dan penarikan kesimpulan adalah upaya untuk mengartikan data yang ditampilkan dengan melibatkan pemahaman

${ }^{13}$ S. Nasution, Metode Research,(Jakarta: Bumi Aksara), h. 113.

${ }^{14}$ Husaini Usman, Metode Penelitian Sosial (Jakarta: Bumi Aksara, 1996), h. 54.

${ }^{15}$ Komaruddin, Kamus Istilah Skripsi dan Tesis (Bandung: Angkasa, 1999), h. 33.

${ }^{16}$ Muhammad Ali,Penelitian Kependidikan Prosedur dan Strategi(Cet. III; Bandung: Angkasa, 1985). h. 85 .

${ }^{17}$ Miles, M. B., Huberman, A. M. t.t. Analisis Data Kualitatif Buku Sumber Tentang Metode-Metode Baru. Terjemahan oleh Tjetjep Rohendi Rohidi.(Jakarta: UI Press, 1992), h. $57 .$.

${ }^{18}$ Sugiyono, Metode Penelitian Kuantitatif Kualitatif dan R\&D (Bandung: Alfabeta, 2008), h. 247.

${ }^{19}$ Miles, M. B., Huberman, A. M. t.t. Analisis Data Kualitatif Buku Sumber Tentang Metode-Metode Baru. Terjemahan oleh Tjetjep Rohendi Rohidi.(Jakarta: UI Press, 1992), h. 63. 
peneliti. ${ }^{20}$ Kesimpulan yang dikemukakan pada tahap awal, didukung oleh bukti-bukti yang valid dan konsisten saat peneliti kembali ke lapangan mengumpulkan data, maka kesimpulan merupakan kesimpulan yang kredibel. ${ }^{21}$ Pada tahap ini dilakukan pengkajian tentang kesimpulan yang telah diambil dengan data yang telah diambil dengan data pembanding teori tertentu; melakukan proses member check atau melakukan proses pengecekan ulang, mulai dari pelaksanaan pra sevey (orientasi), wawancara, observasi, dokumentasi, dan membuat kesimpulan umum untuk dapat dilaporkan sebagai hasil dari penelitian yang telah dilakukan.

Keabsahan data dimaksudkan untuk memperoleh tingkat kepercayaan yang berkaitan dengan seberapa jauh kebenaran hasil penelitian, mengungkapkan dan memperjelas data dengan fakta-fakta aktual dilapangan. Keabsahan data kualitatif harus dilakukan sejak awal pengambilan data, yaitu sejak melakukan reduksi data, display data dan penarikan kesimpulan atau verifikasi. Untuk menguji keabsahan data yangdiperoleh dengan mengukur hasil penelitian ini, dilakukan dengan meningkatkan ketekunan dalam penelitian. ${ }^{22}$ Maka peneliti menggunakan metode triangulasi data yaitu proses penguatan data yang diperoleh dari berbagai sumber yang menjadi bukti temuan. ${ }^{23}$ Yakni melakukan pengamatan secara lebih cermat dan berkesinambungan dengan menggunakan teknik triangulasi.

Menurut Patton dalam Lexy J. Moleong terdapat dua strategi yaitu pengecekan derajat kepercayaan penemuan hasil penelitian beberapa teknik pengumpulan data; dan Pengecekan derajat kepercayaan beberapa sumber data dengan metode yang sama. ${ }^{24}$ Misalnya data diperoleh dengan wawancara, lalu dicek dengan observasi, dokumen atau tes. Bila dengan tiga teknik pengujian kredibilitas data tersebut menghasilkan data yang berbeda-beda, maka peneliti melakukan diskusi lebih lanjut kepada sumber data yang bersangkutan atau yang lain untuk memastikan data mana yang dianggap benar, atau mungkin semuanya benar, karena sudut pandangnya berbeda-beda. Tujuan dari triangulasi ini bukan untuk mencari kebenaran tentang beberapa fenomena, tetapi lebih pada peningkatan pemahaman peneliti terhadap apa yang telah ditemukan.

\section{Hasil dan Pembahasan}

\subsection{Proses Implementasi Manajemen Sumber Daya Manusia dalam Perbaikan Mutu Pelayanan}

Proses implementasi manajemen sumber daya manusia dalam perbaikan mutu pelayanan di Fakultas Tarbiyah dan Keguruan UIN Alauddin Makassar, pada hakekatnya tidak terlepas dari fungsi-fungsi manajemen sumber daya manusia, sebagaimana yang digambarkan dalam fokus penelitian pada bab 1 di atas, yang meliputi; Perencanaan dan desain organisasi, Pengadaan SDM yang meliputi rekrutmen, seleksi dan penempatan, Pelatihan dan pengembangan dalam mencapai tujuan organisasi, Pengawasan, Sistem kompensasi, dan Sistem evaluasi kinerja. Keenam fungsi manajemen sumber daya manusia (SDM) dalam perbaikan mutu pelayanan yang meliputi mutu manajemen layanan; Bimbingan dan Konseling, Bakat dan Minat, Soft Skill, Layanan Beasiswa, dan Layanan Kesehatan pada Fakultas Tarbiyah dan Keguruan UIN Alauddin Makassar.

\subsubsection{Perencanaan dan desain organisasi}

Perencanaan dan desain organisasi merupakan proses awal untuk menetapkan tujuan lembaga atau organisasi, menetapkan apa yang akan diraih selama periode waktu ke depan dan menetapkan tindakan apa yang dilakukan untuk mencapai tujuan tersebut. Dalam manajemen sumber daya

${ }^{20}$ Miles, M. B., Huberman, A. M. t.t. Analisis Data Kualitatif Buku Sumber TentangMetode-Metode Baru. Terjemahan oleh Tjetjep Rohendi Rohidi. (Jakarta: UI Press, 1992), h. 67.

${ }^{21}$ Sugiyono. Memahami Penelitian Kualitiatif Dilengkapi Dengan Contoh Proposal dan Laporan Penelitian, h. 92. 2014)h. 272.

${ }^{22}$ Sugiyono, Metode Penelitian Kuantitatif Kualitatif dan $R \& D$, (Cet. XX; Bandung: Alfabeta,

${ }^{23}$ Emzir, Analisis Data; Metodologi Penelitian Kualitatif (Jakarta: Rajawali Press, 2010), h. 82.

${ }^{24}$ Lexi J. Moleong, Metodologi Penelitian Kualitatif, h. 330. 
manusia (MSDM) perencanaan menjadi titik tumpu untuk mendapatkan SDM yang bermutu untuk selanjutnya diatur sesuai dengan tugas pokok dan fungsi masing-masing.

Perencanaan SDM dilaksanakan oleh pimpinan merujuk Renstra (Rencana Strategi) yang dibentuk dari Visi, Misi, Tujuan, dan Kebijakan yang hendak untuk dicapai. Selain itu, perencanaan sumber daya manusia juga merupakan langkah awal yang dilakukan oleh pimpinan dalam menentukan arah lembaga kedepannya, sebagaimana yang dikemukakan oleh Bapak Dekan sebagai berikut:

Amanah kepemimpinan mengacu Renstra (Rencana Strategi) yang diberikan kepada pimpinan lalu Renop (Rencana Opersioanal). Target Renstra yaitu peningkatan akreditasi sehingga semua hal yang berkaitan dibenahi untuk meningkatkan nilai akreditasi, selalu bekerjasama secara kolektif kologial dan membicarakan secara bersama sehingga keputusan pimpinan sesuai hasil pertemuan yang dilakukan 1 kali sebulan. ${ }^{25}$

Pimpinan mengacu kepada Renstra, namun pimpinan dapat melakukan pembaharuan sistem operasionalnya yang disesuaikan dengan situasi, kondisi, kebutuhan dan target yang ingin dicapai secara bersama. Seperti halnya dengan adanya Forum Group Discussion (FGD) Program Kerja Team Collective Collegial Fakultas Tarbiyah dan Keguruan. Hal yang sama juga diungkapkan oleh Kepala Tata Usaha berkenaan dengan perencanaan dan desain organisasi, lebih lanjut mengemukakan:

Dalam mengelolah suatu lembaga organisasi butuh suatu perencanaan karena tanpa perencanaan manajemen tidak akan berjalan sebab perencanaan meliputi fasilitas dan tenaga kependidikan sehingga perlu dilihat dan direncanakan, hal-hal yang perlu dikelola dan diperbaiki serta yang kurang mesti ditambah. Perencanaan yang matang akan menghasilkan hasil yang lebih baik sehingga hal itu akan berdampak pada kegiatan dalam mengelolah sebuah lembaga. ${ }^{26}$

Hal tersebut menunjukkan perencanaan dan desain organisasi sangatllah urgent baik berupa fasilitas apalagi sumber daya manusianya dan mesti disesuaikan dengan kebutuhan. Berdasarkan hasil wawancara dari semua informan, maka peneliti dapat menarik kesimpulan bahwa perencanaan dan desain organisasi di Fakultas Tarbiyah dan Keguruan berlandaskan rencana strategis (Renstra) dan pimpinan dapat melakukan pembaharuan kepada sistem operasionalnya yang disesuaikan dengan kebutuhan perbaikan pelayanan dan sasaran yang diinginkan secara bersama.

\subsubsection{Pengadaan SDM (Rekrutmen, Seleksi, dan Penempatan)}

Pengadaan sumber daya manusia (SDM) yang meliputi rekrutmen, seleksi dan penempatan pegawai dalam sebuah lembaga dilaksanakan setelah diadakan perencanaan sumber daya manusia. Tujuan pengadaan sumber daya manusia yakni agar sekirannya mendapatkan tenaga kerja dengan kualifikasi yang memadai dan sesuai kebutuhan lembaga. Sistem pengadaan tenaga kepegawaian di Fakultas Tarbiyah dan Keguruan sebagaimana yang dikemukakan oleh Bapak Dekan sebagai berikut:

Tidak ada wewenang fakultas untuk mengangkat pegawai tapi dari hasil analisa sehingga fakultas memberikan rekomendasi ke rektorat. Secara umum kemampuannya terhadap computer telah memadai $90 \%$, kecuali penempatan mutasi dari Rektorat, staf yang baru baik honorer maupun PNS sudah memadai kemampuannya. ${ }^{27}$

Pernyataan tersebut memberikan gambaran bahwa pimpinan memberikan rekomendasi kepada calon pegawai selanjutnya pihak kepegawaian universitaslah yang menentukan disetujui atau tidaknya menjadi tenaga kepegawaian. Adapun penempatannya fakultas menyesesuaikan dengan kualifikasi atau kemampuannya, baik computerisasi, pengarsipan begitupun keuangan. Hal senada

${ }^{25}$ Dr. H. Muhammad Amri, Lc., M.Ag., Dekan, Wawancara, pada tanggal 27 Juni 2019.

${ }^{26}$ Drs. Saharuddin, Kepala Bagian Tata Usaha, Wawancara, pada tanggal 01 Juli 2019, Wawancara, pada tanggal 01 Juli 2019.

${ }^{27}$ Dr. H. Muhammad Amri, Lc., M.Ag., Dekan, Wawancara, pada tanggal 27 Juni 2019. 
juga diungkapkan oleh Wakil Dekan I yakni berkenaan dengan pengadaan tenaga kepegawaian, bahwa:

Kemampuan pegawai yang dimiliki memiliki keterampilan yang baik dan dibimbing terus oleh fakultas, Sebagian melalui otodidak dan sebagian melalui kegitan untuk meningkatkan kemampuan tenaga kepemimpinan tercover dengan baik. Pelatihan untuk empat tahun terakhir lebih banyak soft skill seperti mengundang perusahan-perusahaan dibidang tersebut baik secara Indoor maupun Outdoor. ${ }^{28}$

Pandangan tersebut menggambarkan bahwa pengadaan tenaga kepegawaian sesuai dengan kemampuan dan keterampilannya, fakultas tetap memberikan bimbingan dan pelatihan untuk meningkatkan kemampuan pegawai.

Berdasarkan hasil wawancara dari semua informan, maka peneliti dapat menarik kesimpulan bahwa pengadaan tenaga kepegawaian itu tidak sepenuhnya ditentukan oleh rektoran, dikarenakan pihak fakultas memiliki kewenangan untuk mengusulkan dan merekomendasi calon pegawai kemudian diajukan pihak kepegawaian rektorat, diterima atau tidaknya ditentukan oleh rektorat. Namun penempatannya diatur oleh pihak fakultas, apakah ditempatkan di akademik ataukah sebagai pegawai diruang-ruang jurusan.

\subsubsection{Pelatihan dan Pengembangan dalam Mencapai Tujuan Organisasi}

Pada dasamya tujuan pelatihan dan pengembangan adalah terpenuhinya standar pekerjaan ( $\mathrm{Job}$ Standard) dalam pelaksanaan pekerjaan oleh pegawai atau karyawan secara individual di bidang kerjanya masing-masing. Dengan kata lain tujuan pelatihan adalah terwujudnya perilaku kerja yang semula tidak sesuai menjadi sesuai dengan persyaratan pelaksanaan kerja yang efektif, efisien, produktif dan yang sesuai dengan proses serta hasilnya berkualitas. Sistem pelatihan dan pengembangandi Fakultas Tarbiyah dan Keguruan sebagaimana yang dikemukakan oleh Bapak Dekan sebagai berikut:

Setiap tahun dilaksanakan pembinaan seperti kegiatan pembelajaran komputer, pengarsipan, administrasi serta diikutkan kegiatan pelatihan laboratorium. 1 tahun ini dilakukan kegiatan hipnotherapi sama halnya dengan hipnoteaching yakni untuk pengendalian diri saat bersentuhan dengan mahasiswa, manajemen stres dan pekerjaan rutinnya. ${ }^{29}$

Pernyataan tersebut memberikan gambaran bahwa pimpinan memberikan pembinaan dan pelatihan kepada pegawai baik itu soft skill maupun hard skill, hal tersebut dilakukan untuk mengembangkan kemampuan personal dalam perbaikan mutu pelayanan dalam mencapai tujuan. Hal senada juga diungkapkan oleh Wakil Dekan I yakni berkenaan dengan perencanaan, bahwa:

Fakultas tarbiyah itu sendiri pelatihannya dalam 4 tahun terakhir ini lebih banyak kepelatihan soft skill, kita mengundang perusahaan yang bersentuhan dibidang itu baik indoor mupun outdoor. Fakultas dalam hal ini melakukan pembinaan kepada mereka adapun skill mereka sebagian juga dari otodidat. ${ }^{30}$

Pandangan tersebut menggambarkan bahwa proses pelatihan dan pengembangandiberikan kepada sumber daya manusia fakultas dengan bekerjasama dengan perusahaan yang bersentuhan dengan pelatihan. Fakultas memfasilitasi pelatihan kepada sumber daya manusia dan mengarahkan untuk mengembangkan skill mereka.

\subsubsection{Sistem Pengawasan}

Pengawasan atau kontrol merupakan satu bagian terpenting dalam sebuah manajemen organisasi. Dalam sebuah lembaga atau organisasi walaupun telah dibuat perencanaan secara matang dan pelaksanaannya, namun apabila tidak ada kontrol maka mustahil lembaga tersebut akan mampu

\footnotetext{
${ }^{28}$ Dr. Muljono Damopolii, M.Ag. Wakil Dekan I, Wawancara, pada tanggal 01 Juli 2019

${ }^{29}$ Dr. H. Muhammad Amri, Lc., M.Ag., Dekan, Wawancara, pada tanggal 27 Juni 2019.

${ }^{30}$ Dr. Muljono Damopolii, M.Ag. Wakil Dekan I, Wawancara, pada tanggal 01 Juli 2019
} 
mempertahankan eksistensinya. Adapun Sistem Pengawasan di Fakultas Tarbiyah dan Keguruan sebagaimana yang dikemukakan oleh Bapak Dekan sebagai berikut:

Facelock rutin dan dilakukan pengawasan berjenjang, biasanya pimpinan juga turun langsung untuk mengawasi tanpa sepengetahuan pegawai serta dipantau melalui CCTV. ${ }^{31}$

Pernyataan tersebut memberikan gambaran bahwa pimpinan melakukan pengawas berjenjang yakni adanya facelock, dan pimpinan mengawasi secara langsung begitupula dipantau melalui cctv, karena terkoneksi dengan ruang kepegawaian. Hal senada juga diungkapkan oleh Wakil Dekan I yakni berkenaan dengan pengawasan dalam meningkatkan kedisiplinan:

Sistem kita kolektif kologial jadi semua pegawai merasa diawasi karena tidak ada jarak antara pegawai dengan pimpinan. Facelock diawasi oleh sistem dan dijadikan sebagai bahan untuk mengevaluasi tenaga kependidikan dan tenaga pendidikan. Konsekuensinya yaitu pemberian reward dan digunakan untuk mengecek kehadiran. ${ }^{32}$

Pandangan tersebut menggambarkan bahwa pengawasan dalam meningkatkan kedisiplinan dengan penerapan sistem kolektif kologial jadi pegawai merasa selalu dikontrol oleh pimpinan kerena bekerja bersama sama dan tidak ada jarak antara pegawai dengan atasan. Apalagi adanya sistem facelock yang dijadikan bahan evaluasi oleh pegawai.

\subsubsection{Sistem Kompensasi}

Kompensasi merupakan segala sesuatu yang diterima pegawai atau karyawan dan dosen dalam lembaga pendidikan sebagai balas jasa atas unjuk kerja yang diberikan dalam mendukung dan mewujudkan tujuan maupun program lembaga atau organisasi, baik berupa uang maupun barang yang diberikan secara langsung maupun tidak langsung. Adapun Sistem Kompensasidi Fakultas Tarbiyah dan Keguruan sebagaimana yang dikemukakan oleh Bapak Dekan sebagai berikut; "Gaji pokok sesuai kinerja dan ada remon kinerja, LKP, LKD dan IKU. Saat ini tidak ada penerimaan tunai, semua melalui rekening". ${ }^{33}$

Pernyataan tersebut memberikan gambaran bahwa sistem kompensasinya yakni sesuai dengan kinerja yakni dengan adanya LKP yang mesti diisi setiap harinya oleh pegawai sebab sekarang sistem remunisasi. Penerimaan gaji merekapun langsung diterima melalui rekening.Hal yang sama juga diungkapkan oleh Kepala Tata Usaha berkenaan dengan sistem kompensasi, lebih lanjut mengemukakan:

Remunerasi: Contohnya orang tidak ikut upacara, dikurangi sekian persen yang otomatis berimbas kependapannya, begitu pula jika tidak mengisi SKH maka akan berimbas kekurangan remunerasi. ${ }^{34}$

Hal tersebut menunjukkan sistem kompensasi yang diterapkan sesuai kinerja mereka karena akan berimbas dengan remonnya, seperti kerajinan mengikuti acara dan mengisi SKH secara online.Berdasarkan hasil wawancara dari semua informan, maka peneliti dapat menarik kesimpulan bahwa sistem kompensasi saat ini yakni dinilai dari kinerja dan kehadiran pegawai, jadi setiap hari kerja meraka isi LKPnya tentang apa-apa yang dia kerjakan lalu absensi mereka dilihat dari facelock. Kompensasi pokok pegawai juga tergantung jabatan, jadi untuk pegawai PNS tergantung ketetapan negara dan honorer tergantung ketetapan rektorat.

\subsubsection{Sistem Evaluasi Kinerja}

Penilaian kinerja adalah aktifitas yang dilakukan oleh pimpinan atau manager dalam rangka mengidentifikasi, mengukur dan menetapkan apakah kontribusi dan unjuk kerja yang dilakukan oleh seorang pagawai atau karyawan termasuk di dalamnya dosen atau tenaga pendidik itu sukses atau gagal, dan dengan adanya sistem Reward dan Punishment. Adapun Sistem Evaluasi Kinerjadi

${ }^{31}$ Dr. H. Muhammad Amri, Lc., M.Ag., Dekan, Wawancara, pada tanggal 27 Juni 2019.

${ }^{32}$ Dr. Muljono Damopolii, M.Ag. Wakil Dekan I, Wawancara, pada tanggal 01 Juli 2019

${ }^{33}$ Dr. H. Muhammad Amri, Lc., M.Ag., Dekan, Wawancara, pada tanggal 27 Juni 2019.

${ }^{34}$ Drs. Saharuddin, Kepala Bagian Tata Usaha, Wawancara, pada tanggal 01 Juli 2019, Wawancara, pada tanggal 01 Juli 2019. 
Fakultas Tarbiyah dan Keguruan sebagaimana yang dikemukakan oleh Bapak Dekan sebagai berikut:

Selalu ada pertemuan, reward-nya diusulkan pegawai teladan sehingga mendapatkan bonus. Promosi/ pengangkatan \& Study tour. Adapun Punishment berupa tuguran maupun tulisan. 35

Pernyataan tersebut memberikan gambaran bahwa pimpinan dalam mengevaluasi kinerja pegawai dangan memakai sistem reward dan punishment. Jika berprestasi maka dipromosikan atau pengangkatan. Adapun punishment-nya yaknii awalnya berupa teguran lisan dan jika tidak ada perubahan maka dengan teguran tertulis. Hal senada juga diungkapkan oleh Wakil Dekan I yakni berkenaan dengan sistem evaluasi kinerja:

Reward-nya jika ada pegawai tugasnya membutuhkan laptop yang lebih baik maka dibelikan laptop. Punishment pegawai dengan dikurangi keikutsertaannya dalam kepanitiaan atau di rolling. ${ }^{36}$

Pandangan tersebut menggambarkan bahwa sistem evaluasi kinerja dengan sistem reward dan punishment, jika kinerjanya baik maka disiapkan fasilitas yang lebih baik seperti jika membutuhkan laptop yang lebih baik maka disiapkan, namun jika pegawai tersebut kurang kinerjanya maka hukumannya berupa dikurangngi keikut sertaanya dalam kegiatan-kegitan bahkan di rolling.

Berdasarkan hasil wawancara dari semua informan, maka peneliti dapat menarik kesimpulan bahwa sistem evaluasi kinerja di Fakultas Tarbiyah dan Keguruan dengan memberikan reward dan punishment, jika kinerja pegawai bagus dan disiplin maka akan diberi reward baik kenaikan pangkat ataukah lainya. Namun jika ada pegawai kurang disiplin dan kinerjanya kurang baik awalnya diberi teguran dan jika tidak ada perubahan maka di beri teguran tertulis dan jika tidak ada perkembangan maka di pindahkan jabatannya.

\subsection{Faktor Pendukung dan Penghambat dalam Implemantasi Manajemen Sumber Daya Manusia}

Bidang garapan mutu pelayanan pendidikan meliputi semua tindakan yang menjadi penunjang proses belajar mengajar dalam rangka mencapai tujuan pendidikan yang telah ditetapkan. Dengan demikian mereview pengelolaan mutu pelayanan lembaga pendidikan merupakan pengecekan seluruh komponen atau program kegiatan pendidikan, baik yang sedang berjalan maupun akan dilaksanakan. Adapun Faktor pendukung dan faktor penghambat sebagaimana yang dikemukakan oleh Bapak Dekan sebagai berikut:

Kemistri fakultas sudah ketemu yaitu sama-sama untuk membawa fakultas lebih baik sehingga mudah dicapai. Adapun hambatannya yakni anggaran dan regulasi. ${ }^{37}$

Pernyataan tersebut memberikan gambaran bahwa seluruh stakeholder mendukung full kebijakan dan program-program fakultas, dengan sistem kolektif kologial. Adapun hambatan yang ada yakni keterbatasan anggaran dan regulasi. Hal senada juga diungkapkan oleh Wakil Dekan I yakni berkenaan dengan faktor pendukung dan faktor penghambat, yakni:

Pendukungnya yakni Komitmen pimpinan sangat kuat untuk merajut kebersamaan, pimpinan kolektif kologial itu dilakukan bersama-sama. Adapun dari segi penghambat yakni fakultas ini sangat besar, keterjangkauan itu juga seperti pendanaan yang semakin intens, keterjangkauan dalam berkomunikasi dengan orang. Apalagi difakultas itu komposisinya ada pegawai yang sudah senior itu membutuhkan pekerjaan yang spesial. Saat ini sarana prasarana dengan rasio mahasiswa sekarang kita memiliki gedung perkuliahan yang banyak, gedung utama ini hanya dipakai sampai siang adapun gedung $R$ dipakai sampai sore, itu berarti kita masih memiliki banyak persediaan ruangan untuk proses perkuliahan. ${ }^{38}$

\footnotetext{
${ }^{35}$ Dr. H. Muhammad Amri, Lc., M.Ag., Dekan, Wawancara, pada tanggal 27 Juni 2019.

${ }^{36}$ Dr. Muljono Damopolii, M.Ag. Wakil Dekan I, Wawancara, pada tanggal 01 Juli 2019

${ }^{37}$ Dr. H. Muhammad Amri, Lc., M.Ag., Dekan, Wawancara, pada tanggal 27 Juni 2019.

${ }^{38}$ Dr. Muljono Damopolii, M.Ag. Wakil Dekan I, Wawancara, pada tanggal 01 Juli 2019
} 
Pandangan tersebut menggambarkan bahwa faktor pendukungnya itu komitmen pimpinan yang sangat kuat dalam sistem kepemimpinan kolektif kologial dengan keputusan dan dikerjakan secara bersama sama. Faktor penghambatnya yakni dari segi pendanaan dan keterjangkauan komunikasi, pegawai yang sudah senior membutuhkan pekerjaan yang spesial. Hal yang sama juga diungkapkan oleh Kepala Tata Usaha berkenaan dengan faktor pendukung dan faktor penghambat, lebih lanjut mengemukakan:

Melalui bimbingan, melalui SEMA, DEMA dan HMJ, menyediakan fasilitas bakat dan minat, menyediakan fasilitas seni dan budaya seperti tari, pemberian pelatihan. ${ }^{39}$

Hal tersebut menunjukkan faktor pendukungnya yakni dengan kerjasama baik dengan pengurus lembaga kemahasiswaan, fasilitas seni dan olah raga beserta dengan adanya pelatihan-pelatihan.

Berdasarkan hasil wawancara dari semua informan, maka peneliti dapat menarik kesimpulan bahwa faktor pendukungnya yakni Stakeholder mendukung full kebijakan dan program-program fakultas dengan sistem kolektif kologial; Pimpinan memberikan pelatihan soft skill dan hard skill; Pimpinan membuka ruang seluas luaskan untuk pengembangan diri; Ketersediaan fasilitas panggung seni dan pekan olah raga; kerjasama baik dengan pengurus lembaga kemahasiswaan, Adapun faktor penghambatnya yakni keterbatasan anggaran, regulasi, keterjangkauan komunikasi, pegawai yang sudah senior membutuhkan pekerjaan yang spesial, dan jika server pusat mengalami gangguan.

\subsection{Hasil Implemantasi Manajemen Sumber Daya Manusia dalam Perbaikan Mutu Pelayanan}

\subsubsection{Bimbingan dan Konseling}

Bimbingan dan Konseling adalah proses interaksi antara konselor dengan konseli baik secara langsung maupun tidak langsung dalam rangka untuk membantu konseli agar dapat mengembangkan potensi dirinya atau pun memecahkan permasalahan yang dialaminya. ${ }^{40}$ Sistem Bimbingan dan Konselingdi Fakultas Tarbiyah dan Keguruan sebagaimana yang dikemukakan oleh Bapak Dekan sebagai berikut:

Disiapkan penasehat akademik, ketua jurusan dan sekretaris jurusan dan wakil dekan kemahasiswaan, persoalan yang benar benar krusia disampaikan ke Dekan. Saat ini One day servise, berusaha diselesaikan dalam 1 hari kecuali ada dinas diluar. ${ }^{41}$

Pernyataan tersebut memberikan gambaran bahwa layanan bimbingan dan konseling diberikan kepada mahasiswa dengan adanya penasehat akademik lalu ada pula pihak jurusan dan wakil dekan kemahasiswaan menangani hal tersebut. Hal senada juga diungkapkan oleh Wakil Dekan III yakni berkenaan dengan layanan bimbingan dan konseling, bahwa:

Bimbingan dan konseling dengan memberikan nasehat dan petunjuk agar bisa belajar dengan baik dan berorganisasi sesuai dengan buku saku universitas dan menyampaikan melalui HMJ, DEMA dan SEMA. ${ }^{42}$

Pandangan tersebut menggambarkan bahwa layanan bimbingan dan konseling diterapkan oleh wakil dekan III dengan memberikan nasehat, motivasi agar belajar dengan baik memberikan kesempatan untuk belajar berorganisasi sesuai dengan buku saku universitas yang dibagikan ke mahasiswa dan adapun penyampaian bimbingan konseling disampaikan melalui pengurus lembaga.

Berdasarkan hasil wawancara dari semua informan, maka peneliti dapat menarik kesimpulan bahwa layanan bimbingan dan konseling di Fakultas Tarbiyah Dan Keguruan dilaksanakan dengan baik, mulai dari penasehat akademik, dosen diawal memulai perkuliahan, pihak jurusan dalam melayani keperluan mahasiswa begitu pula pimpinan yakni wakil dekan bagian mahasiswa biasanya

${ }^{39}$ Prof. Dr. H. Syahruddin, M.Pd. Wakil Dekan III, Wawancara, pada tanggal 28 Juni 2019.

${ }^{40}$ Peraturan Menteri Pendidikan dan Kebudayaan Republik Indonesia Nomor 111 Tahun 2014 tentang Bimbingan dan Konseling pada Pendidikan Dasar dan Pendidikan Menengah, diakses pada tanggal 07 Maret 2019, h. 2.

${ }^{41}$ Dr. H. Muhammad Amri, Lc., M.Ag., Dekan, Wawancara, pada tanggal 27 Juni 2019.

${ }^{42}$ Prof. Dr. H. Syahruddin, M.Pd. Wakil Dekan III, Wawancara, pada tanggal 28 Juni 2019. 
mengadakan pertemuan dengan para pengurus lembaga kemudian disaat itulah memberikan bimbingan, nasehat kepada pengurus lalu mengarahkan agar meneruskan ke anggota masingmasing.

\subsubsection{Bakat dan Minat}

Bakat adalah kemampuan dasar seseorang untuk belajar dalam tempo yang relatif pendek dibandingkan orang lain, namun hasilnya justru lebih baik. Bakat merupakan potensi yang dimiliki oleh seseorang sebagai bawaan sejak lahir. Minat ialah suatu proses pengembangan dalam mencampurkan seluruh kemampuan yang ada untuk mengarahkan individu kepada suatu kegiatan yang diminatinya. ${ }^{43}$

Sistem layanan bakat dan minat di Fakultas Tarbiyah dan Keguruan sebagaimana yang dikemukakan oleh Bapak Dekan sebagai berikut; "Kesempatan berkreasi dibuka luas, namun tidak melampaui aturan yang ditentukan. Fasilitas olah raga untuk mahasiswa dan dosen". ${ }^{44}$

Pimpinan memberikan ruang dan membuka kesempatan kepada mahasiswa untuk berkreasi dalam pengembangan bakat dan minat masing-masing asalkan tidak melampaui batas. Dengan disiapkannya Fasilitas baik olah raga dan seni. Hal senada juga diungkapkan oleh Wakil Dekan III yakni berkenaan dengan layanan bakat dan minat, bahwa; "Pimpinan memberikan kesempatan kepada mahasiswa untuk mengembangkan bakatnya dengan menyediakan fasilitas dan mengikuti lomba-lomba". 45

Pandangan tersebut menggambarkan bahwa pimpinan memberikan layanan bakat dan minat dengan membuka kesempatan kepada mahasiswa untuk pengembangan bakatnya dengan menyediakan fasilitas dan mensupport untuk mengikuti beberapa pekan perlombaan. Hal yang sama juga diungkapkan oleh Kepala Tata Usaha berkenaan dengan layanan bakat dan minat, lebih lanjut mengemukakan:

Senantiasa memberi pengarahan dan pelayanan untuk mengembangkan minat dan bakatnya seperti extrakulikuler, tari, tidak dihalangi namun tetap diawasi. Program panggung diberikan kepada mahasiswa untuk mengembangkan bakat. Satu satunya panggung di universitas yaitu fakultas tarbiyah disanalah mereka diskusi dan mengadakan lomba. ${ }^{46}$

Hal tersebut menunjukkan layanan bakat dan minat dengan senantiasa diberikan ruang untuk pengembangan mahasiswa seperti kegiatan ektrakulikuler seperti seni drama, seni dan lain sebagainnya. Ada panggung disiapkan untuk mengekspresikan diri dan mengembangkan bakat mahasiswa. Selanjutnya secara spesifik dipaparkan oleh Kepala Sub Bagian Akademik, Kemahasiswaan, dan Alumni bahwa:

Organisasi olahraga, LDF, IMM, Seni/ Estetika. Penyalurannya melalui berbagai organisasi yang setiap fakultas mempunyai organisasi masing-masing. Kegiatan jurusan melibatkan mahasiswa sendiri, sama halnya juga kalau ada acara wisuda maka siapa yang panitia maka memanggil mahasiswa untuk pengisi acara. Mahasiswa dilibatkan sebagai pembelajaran buat mereka. Ada pekan olah raga mulai lomba dari jurusan lalu dilanjut tingkat fakultas lalu universitas. Contohnya lomba menulis. Poros intim berangkat ke Malang bulan Juli tingkat universitas bagian seni yaitu lomba Tilawah. ${ }^{47}$

Penjelasan di atas memberikan gambaran bahwa pimpinan memberikan layanan pengembangan bakat dan minat denganadanya organisasi seni, olah raga, lembaga dakwah fakultas dan lembaga

${ }^{43}$ Suryadi, Perilaku Anak Usia Dini Kasus dan Pemecahannya, (Yogyakarta: Kanisius, 2003),h.16.

${ }^{44}$ Dr. H. Muhammad Amri, Lc., M.Ag., Dekan, Wawancara, pada tanggal 27 Juni 2019.

${ }^{45}$ Prof. Dr. H. Syahruddin, M.Pd. Wakil Dekan III, Wawancara, pada tanggal 28 Juni 2019.

${ }^{46}$ Drs. Saharuddin, Kepala Bagian Tata Usaha, Wawancara, pada tanggal 01 Juli 2019, Wawancara, pada tanggal 01 Juli 2019.

${ }^{47}$ Jumrah, S.Ag., Kepala Sub Bagian Akademik, Kemahasiswaan, Dan Alumni, Wawancara, pada tanggal 28 Juni 2019. 
ekstra. Kegiatan jurusan melibatkan mahasiswa sendiri lalu mengikutkan lomba tingkat fakultas dan selanjutnya diikutkan dilomba universitas, bahkan mengikutkan lomba di luar lingkup universitas.

Berdasarkan hasil wawancara dari semua informan, maka peneliti dapat menarik kesimpulan bahwa layanan pengembangan bakat dan minatdi Fakultas Tarbiyah dan Keguruan diarahkan dan difasilitasi oleh pihak pimpinan. Seperti halnya dengan disiapkannya panggung ekspresi, ruang teater dan lapangan olah raga bahkan disiapkan pekan olah raga dan seni mulai dari tingkat jurusan hingga universitas.

\subsubsection{Soft Skill}

Soft skills tidak terlihat kasat mata dibandingkan kemampuan teknis, dan untuk memperolehnya tidak serta merta harus mengikuti sebuah kelas pelatihan. Mahasiswa dapat memperoleh soft skill melalui pengalaman diperkuliahan, pengalaman hidup dan masa lalu, atau pengalaman dalam dunia kerja yang tengah dilakoni. Pengalaman tersebut merupakan sebuah pembelajaran sangat berharga sehingga mahasiswa dapat menjalani peran sebagai seorang professional yang tidak hanya handal dalam urusan teknis, namun sangat lihai berhubungan dengan orang lain. Sistem pelatihan soft skilldi Fakultas Tarbiyah dan Keguruan sebagaimana yang dikemukakan oleh Bapak Dekan sebagai berikut:

Kegiatan Pelatihan dan pembinaan soft skill diarahkan kepada lembaga, lembaga mahasiswa mengkonsultasikan ke bagian fakultas. Lembaga mahasiswa seperti dewan eksekutif mahasiswa (DEMA) dan himpunan mahasiswa jurusan (HMJ) rutin melakukan kegiatan-kegiatan pelatihan seperti latihan dasar kepemimpinan. ${ }^{48}$

Pimpinan memfasilitasi mahasiswa melalui lembaga lembaga kemahasiswaan, sama halnya jika pengurus lembaga ingin melaksanakan lembaga maka mengkonsultasikan kepada pimpinan fakultas. Latihan dasar kepimpinan rutin dilaksanakan di masing masing jurusan. Hal senada juga diungkapkan oleh Wakil Dekan III yakni berkenaan dengan Sistem soft skill, bahwa; "Pelatihan soft skill dengan pelatihan baca tulis al-qur'an dan memotivasi untuk mengikuti pelatihan diluar". ${ }^{49}$

Pandangan tersebut menggambarkan bahwa pelatihan soft skill diberikan kemahasiswa seperti halnya baca tulis al-qur'an dan pelatihan-pelatihan yang dapat memotivasi mereka dan memfasilitasi jika ada pelatihan luar lingkup fakultas. Hal yang sama juga diungkapkan oleh Kepala Tata Usaha berkenaan dengan pelatihan soft skill, lebih lanjut mengemukakan; "Untuk saat ini kegiatan dilakukan oleh himpunan mahasiswa jurusan dan dewan mahasiswa dan senat mahasiswa". ${ }^{50}$

Hal tersebut menunjukkan pelatihan soft skill difasilitasi oleh fakultas namun kegiatankegiatannya langsung dilaksanakan oleh lembaga-lembaga kemahasiswaan, seperti HMJ, DEMA dan SEMA.Selanjutnya secara spesifik dipaparkan oleh Kepala Sub Bagian Akademik, Kemahasiswaan, dan Alumni bahwa; "Ada pelatihan soft skill setiap tahunnya, seperti yang barubaru ini ke Malino, Tanjung Akkarena dalam rangka pelatihan outdoor". 51

Berdasarkan hasil wawancara dari semua informan, maka peneliti dapat menarik kesimpulan bahwa pelatihan soft skill di Fakultas Tarbiyah dan Keguruan difasilitasi oleh pimpinan dan dilaksanakan langsung oleh pengurus lembaga kemahasiswaan, baik itu HMJ, DEMA dan SEMA bahkan oleh organisasi-organisasi ekstra. Adapun pelatihannnya yakni latihan dasar kepemimpinan, jurnalis, kewirausahaan dan pengkaderan oleh organisasi ekstra. Diizinkan dan difasilitasi oleh pimpinan dengan memasukkan proposal kegiatan dan asalkan tidak melampaui batas.

${ }^{48}$ Dr. H. Muhammad Amri, Lc., M.Ag., Dekan, Wawancara, pada tanggal 27 Juni 2019.

${ }^{49}$ Prof. Dr. H. Syahruddin, M.Pd. Wakil Dekan III, Wawancara, pada tanggal 28 Juni 2019.

${ }^{50}$ Drs. Saharuddin, Kepala Bagian Tata Usaha, Wawancara, pada tanggal 01 Juli 2019, Wawancara, pada tanggal 01 Juli 2019.

${ }^{51}$ Jumrah, S.Ag., Kepala Sub Bagian Akademik, Kemahasiswaan, Dan Alumni, Wawancara, pada tanggal 28 Juni 2019. 


\subsubsection{Layanan Beasiswa}

Layanan Beasiswa adalah pemberian berupa bantuan keuangan yang diberikan kepada perorangan yang bertujuan untuk digunakan demi keberlangsungan pendidikan yang ditempuh. Beasiswa dapat diberikan oleh lembaga pemerintah, perusahaan ataupun yayasan. Adapun Sistem Layanan Beasiswadi Fakultas Tarbiyah dan Keguruan sebagaimana yang dikemukakan oleh Bapak Dekan sebagai berikut:

Layanan beasiswa yang kami berikan masih sangat terikat dengan rektorat, masing-masing fakultas diberi jatah kemudian diseleksi disetiap jurusan. Adapun beasiswa yang ada yakni bidik misi dan berprestasi. ${ }^{52}$

Pernyataan tersebut memberikan gambaran bahwa pimpinan memfasilitasi mahasiswa dengan layanan beasiswa, namun beasiswa yang diberikan masih terikat dengan rektorat. Sistem layanannya yakni fakultas memberikan wewenang kepada jurusan masing-masing untuk menyeleksi anggotanya dalam program beasiswa. Beasiswa yang ada yakni bidik misi dan berprestasi. Hal senada juga diungkapkan oleh Wakil Dekan III yakni berkenaan dengan sistem layanan beasiswa, bahwa:

Mahasiswa akan mengikuti persyaratan dan petunjuk untuk mendapatkan beasiswa, adapun beasiswa dari BI, beasiswa penghafal Al-Qur'an dan Kemenag. Pihak fakultas memberikan surat berkelakuan baik. ${ }^{53}$

Pandangan tersebut menggambarkan bahwa sistem layanan beasiswa itu dengan mahasiswa mengikuti dan melengkapi persyaratan beasiswa, biasanya fakultas memberikan surat keterangan berkelakuan baik. Adapun layanan beasiswa yang disiapkan dari BI, beasiswa tahfidz dan dari Kemenag.

Sistem layanan beasiswa disediakan oleh pimpinan, namun tidak lepas dari jatah yang diberikan oleh rektorat. Jatah beasiswa yang didapatkan dibagi ke jurusan masing-masing untuk menyeleksi mahasiswa dijurusannya. Bervariasi beasiswa yang ada yakni berprestasi dan kurang mampu dan beasiswa tersebut berasal dari BI, Kemenag, BRI, dan pemerintah daerah, dan lain sebagainya.

\subsubsection{Layanan Kesehatan}

Pelayanan kesehatan adalah sebuah konsep yang digunakan dalam memberikan layanan kesehatan kepada masyarakat. Sebuah sub sistem pelayanan kesehatan yang tujuan utamanya adalah pelayanan preventif (pencegahan) dan promotif (peningkatan kesehatan) dengan sasaran masyarakat kampus maupun masyarakat umum. Sistem Layanan Kesehatan di Fakultas Tarbiyah dan Keguruan sebagaimana yang dikemukakan oleh Bapak Dekan sebagai berikut:

Layanan kesehatan melalui poliklinik yang biasanya diantarkan langsung menggunakan mobil fakultas, mobil pihak jurusan maupun kendaraan mahasiswa. ${ }^{54}$

Pernyataan tersebut memberikan gambaran bahwa ada layanan kesehatan diberikan ke mahasiswa yakni melalui poliklinik, jika ada mahasiswa yang sakit maka pihak fakultas menghubungi pihak poliklinik bahkan langsung membawanya dengan menggunakan kendaraan pimpinan. Hal senada juga diungkapkan oleh Wakil Dekan III yakni berkenaan dengan layanan kesehatan, bahwa; "Layanan kesehatan diberikan melalui pelayanan klinik Alauddin, jika ada mahasiswa yang sakit maka kita conteck dan bawah segera ke klinik". ${ }^{55}$

Layanan kesehatan yang disiapkan melalui pelayanan kesehatan klinik Alauddin. Jika ada yang sakit baik mahasiswa ataukan pegawai maka pimpinan menghubungi pihak klinik bahkan langsung mengantarnya.Hal yang sama juga diungkapkan oleh Kepala Tata Usaha berkenaan dengan layanan

\footnotetext{
${ }^{52}$ Dr. H. Muhammad Amri, Lc., M.Ag., Dekan, Wawancara, pada tanggal 27 Juni 2019.

${ }^{53}$ Prof. Dr. H. Syahruddin, M.Pd. Wakil Dekan III, Wawancara, pada tanggal 28 Juni 2019.

${ }^{54}$ Dr. H. Muhammad Amri, Lc., M.Ag., Dekan, Wawancara, pada tanggal 27 Juni 2019.

${ }^{55}$ Prof. Dr. H. Syahruddin, M.Pd. Wakil Dekan III, Wawancara, pada tanggal 28 Juni 2019.
} 
kesehatan, lebih lanjut mengemukakan; "Poliklinik menampung siapa saja baik mahasiswa, pegawai dan dosen bahkan masyarakat dengan cara langsung kesana". ${ }^{56}$

Layanan kesehatan terbuka untuk semua stakeholder, jadi mahasiswa atau pegawai bisa langsung ke poliklinik. Berdasarkan hasil wawancara dari semua informan, maka peneliti dapat menarik kesimpulan bahwa layanan kesehatan diperhatikan oleh pimpinan, seperti halnya jika ada yang sakit maka langsung menelpon ke poliklinik dan bahkan langsung mengantar dengan mengunakan kendaaan fakultas tanpa menunggu ambulance. Fasilitas layanan kesehatan terbuka untuk semua masyarakat kampus, dan untuk mahasiswa membawa KTM.

\section{Simpulan}

Ada 3 hal yang dapat disimpulkan, yakni Proses implementasi manajemen sumber daya manusia dalam perbaikan mutu pelayanan Fakultas Tarbiyah dan Keguruan UIN Alauddin Makassar, menunjukkan telah sesuai dengan standar atau aturan; Faktor pendukung dan penghambat implementasi manajemen sumber daya manusia dalam perbaikan mutu pelayanan Fakultas Tarbiyah dan Keguruan UIN Alauddin Makassar. (a) Faktor pendukungnya yakni Stakeholders mendukung sepenuhnya kebijakan dan program-program fakultas dengan sistem kolektif kologial; Pimpinan memberikan pelatihan soft skill dan hard skill; Pimpinan membuka ruang seluas luaskan untuk pengembangan diri; .Ketersediaan fasilitas panggung seni dan pekan olah raga; kerjasama baik dengan pengurus lembaga kemahasiswaan, (b) Faktor penghambatnya yakni keterbatasan anggaran, regulasi, keterjangkauan komunikasi, pegawai yang sudah senior membutuhkan pekerjaan yang spesial, dan jika server pusat mengalami gangguan; dan Hasil implementasi manajemen sumber daya manusia dalam perbaikan mutu pelayanan Fakultas Tarbiyah dan Keguruan UIN Alauddin Makassar, menunjukkan perkembangan yang lebih baik, namun tetap masih diperlukan upaya pembinaan secara optimal agar mutu manajemen layanan melebihi harapan pelanggan.

\section{Daftar Pustaka}

Saiful Sagala, Manajemen Strategik dalam Peningkatan Mutu Pendidikan, (Bandung: Alfabeta, 2004), h. 100.

Tim Redaksi Kemenag, Peraturan Menteri Agama RI No.20 Thn 2014 tentang Statuta UIN Alauddin Makassar, (Jakarta, 2014), h. 27.

Johannes Gunawan, Kebijakan Nasional Sistem Penjaminan Mutu Internal, (Jakarta: Kemenrisetdikti, 2017), h. 6.

Tim Redaksi Sinar Grafika, Permenristekdikti No. 44 Tahun 2015, tentangStandar Nasional Pendidikan Tinggi (Jakarta: Sinar Grafika, 2013), h. 2.

Nur Aedi, Dasar-Dasar Manajemen Pendidikan, (Yogyakarta: Gosyen, 2015), h.162.

Kementerian Agama RI, Al-Qur'an Terjemahnya (Jakarta: PT. Tahazed, 2015) h. 273.

Marwan bin Musa, Tafsir Al Qur'anil Azhiim (Isma'il bin Katsir)Maktabah Syamilahversi 3.45. h.237.

Sugiyono, Memahami Penelitian Kualitatif (Cet. IV; Bandung: CV. Alfabeta, 2008), h.205.

Nata, Abuddin. Metodologi Studi Islam (Cet.XI; Jakarta: PT. Raja Grafindo Persada, 2004), h.51.

Moh. Kasiram, Metode penelitian Kualitatif-Kuantitatif,(Malang: UIN Malang Press, 2008), h. 231.

Marzuki, Metodologi Riset,(Yogyakarta: t.pn, 2008), h. 55.

S. Nasution, Metode Research,(Jakarta: Bumi Aksara), h. 113.

Husaini Usman, Metode Penelitian Sosial (Jakarta: Bumi Aksara, 1996), h. 54.

${ }^{56}$ Drs. Saharuddin, Kepala Bagian Tata Usaha, Wawancara, pada tanggal 01 Juli 2019, Wawancara, pada tanggal 01 Juli 2019. 
Komaruddin, Kamus Istilah Skripsi dan Tesis (Bandung: Angkasa, 1999), h. 33.

Muhammad Ali,Penelitian Kependidikan Prosedur dan Strategi(Cet. III; Bandung: Angkasa, 1985). h. 85.

Miles, M. B., Huberman, A. M. t.t. Analisis Data Kualitatif Buku Sumber Tentang Metode-Metode Baru. Terjemahan oleh Tjetjep Rohendi Rohidi.(Jakarta: UI Press, 1992), h. $57 .$.

Sugiyono, Metode Penelitian Kuantitatif Kualitatif dan R\&D (Bandung: Alfabeta, 2008), h. 247.

Miles, M. B., Huberman, A. M. t.t. Analisis Data Kualitatif Buku Sumber Tentang Metode-Metode Baru. Terjemahan oleh Tjetjep Rohendi Rohidi.(Jakarta: UI Press, 1992), h. 63.

Sugiyono, Metode Penelitian Kuantitatif Kualitatif dan R\&D , (Cet. XX; Bandung: Alfabeta, 2014)h. 272.

Emzir, Analisis Data; Metodologi Penelitian Kualitatif (Jakarta: Rajawali Press, 2010), h. 82.

H. Muhammad Amri, Lc., M.Ag., Dekan, Wawancara, pada tanggal 27 Juni 2019.

Saharuddin, Kepala Bagian Tata Usaha, Wawancara, pada tanggal 01 Juli 2019, Wawancara, pada tanggal 01 Juli 2019.

Muljono Damopolii, M.Ag. Wakil Dekan I, Wawancara, pada tanggal 01 Juli 2019

H. Syahruddin, M.Pd. Wakil Dekan III, Wawancara, pada tanggal 28 Juni 2019.

Peraturan Menteri Pendidikan dan Kebudayaan Republik Indonesia Nomor 111 Tahun 2014 tentang Bimbingan dan Konseling pada Pendidikan Dasar dan Pendidikan Menengah, diakses pada tanggal 07 Maret 2019, h. 2.

Suryadi, Perilaku Anak Usia Dini Kasus dan Pemecahannya, (Yogyakarta: Kanisius, 2003),h.16.

Jumrah, S.Ag., Kepala Sub Bagian Akademik, Kemahasiswaan, Dan Alumni, Wawancara, pada tanggal 28 Juni 2019. 